\title{
Vascular epiphytes in the Grumari restinga, RJ: floristic and similarities between restingas in Eastern Brazil
}

\author{
Dayvid Rodrigues Couto ${ }^{1,4}$, Fernando Perez Uribbe ${ }^{1}$, Suara S.A. Jacques ${ }^{1}$, Talitha Mayumi Fracisco ${ }^{2}$ \\ \& Rosana C. Lopes ${ }^{1,3}$
}

\begin{abstract}
The community of vascular epiphytes in the Grumari restinga, Rio de Janeiro state, was evaluated through surveys carried out in 2014 and supplemented with herbarium material and publications. Thirty-seven (37) vascular epiphyte species were recorded, distributed in 21 genera and six families. The richest families are Orchidaceae and Bromeliaceae, which are the most representative ones (67.6\% of all record species). The richness in Grumari restinga is greater than the other inventories carried out in the coastal plain of the Southeastern Region of Brazil, however, lower than that of restingas for São Paulo, Paraná and of the coastal plain of Rio Grande do Sul. The most representative ecological category was the characteristic holoepiphyte (62\%); it was followed by the facultative and accidental holoepiphytes (18\% each). The Grumari restinga shares more species with Espírito Santo state and Rio de Janeiro than with São Paulo and Southern Region of Brazil, possibly due to the geographical distance. Our study provides the first contribution to the knowledge about the epiphytic flora in Grumari resting $a$ and shows a singular flora with $40 \%$ of unique species occurring in this location, fact that justifies its importance as conservation area. Key words: Atlantic domain, coastal vegetation, conservation, flora, taxonomy.

\section{Resumo}

A comunidade de epífitas vasculares ocorrente na restinga de Grumari, estado do Rio de Janeiro, foi avaliada através de coletas realizadas no ano de 2014 e complementadas com materiais de herbários e publicações. 37 espécies de epífitas vasculares foram registradas, distribuídas em 21 gêneros e seis famílias. As famílias mais ricas são Orchidaceae e Bromeliaceae, que foram as mais representativas (67,6\% de todas as espécies registradas). A riqueza na restinga de Grumari é maior do que os outros inventários realizados na planície costeira do Sudeste do Brasil, no entanto, inferior as restingas de São Paulo, Paraná e da planície costeira do Rio Grande do Sul. A categoria ecológica mais representativa foi a holoepífita característica (62\%) seguida por holoepífitas facultativas e acidentais com $18 \%$ cada. A restinga de Grumari possui mais espécies em comum com as restingas do Espírito Santo e Rio de Janeiro do que com São Paulo e região Sul do Brasil, possivelmente em função da distância geográfica. Nosso estudo traz a primeira contribuição ao conhecimento da flora epifítica da restinga de Grumari e evidencia uma flora singular com $40 \%$ das espécies exclusivas dessa localidade, o que justifica sua importância como Unidade de Conservação.
\end{abstract}

Palavras-chave: Domínio Atlântico, vegetação costeira, conservação, flora, taxonomia.

\footnotetext{
${ }_{1}^{1}$ Universidade Federal do Rio de Janeiro, Prog. Pós-graduação em Botânica, Museu Nacional, Quinta da Boa Vista, São Cristóvão, 20940-040, Rio de Janeiro, RJ, Brazil.

${ }^{2}$ Universidade Estadual do Norte Fluminense - Darcy Ribeiro, Prog. Pós-graduação em Ecologia e Recursos Naturais, Lab. Ciências Ambientais, Av. Alberto Lamego, Parque California, 28035-200, Campos dos Goytacazes, RJ, Brazil.

${ }^{3}$ Universidade Federal do Rio de Janeiro, Inst. Biologia, Depto. Botânica, R. Prof. Rodolpho Paulo Rocco s/n, Prédio do CCS, Bl. A, Ilha do Fundão, 21941-901, Rio de Janeiro, RJ, Brazil.

${ }^{4}$ Author for correspondence: dayvidcouto@hotmail.com
} 


\section{Introduction}

Vascular epiphytes are a well-known feature in tropical and subtropical rainforests and are important floristic, structural and functional components of these ecosystems (Gentry \& Dodson 1987; Krömer et al. 2007; Ding et al. 2016), thus representing approximately $9 \%$ of the world's vascular flora (Zotz 2013). The Brazilian Atlantic Rainforest is recognized as one of the five most important world hotspots (Myers et al. 2000), where vascular epiphytes represent approximately $15 \%$ (2.256 species) of the known vascular plants (Freitas et al. 2015) from this domain, with greater richness and endemism located in the states of Rio de Janeiro and Espírito Santo (Menini Neto et al. 2015). In Brazil, most studies concentrate on the southern and southeastern regions, especially in ecosystems associated with the Atlantic rainforest domain, such as the dense ombrophilous forest (Blum et al. 2011; Freitas \& Assis 2013; Hoeltgebaum et al. 2013; Barbosa et al. 2015; Furtado \& Menini Neto 2015; Wängler et al. 2015), mixed ombrophilous forest (Kersten \& Kuniyoshi 2009; Alves \& Menini Neto 2014), deciduous and seasonal semideciduous forest (Rogalski \& Zanin 2003;Dettke et al. 2008; Barbosa et al. 2015; Basílio et al. 2015; Dislich \& Mantovani 2016; Couto et al. 2016b), restinga forests (Kersten \& Silva 2006; Fontoura et al. 2009; Mania \& Monteiro 2010; Staudt et al. 2012) and granite and gneiss inselbergs (Couto et al. 2016a).

Restingas represent one of the most important ecosystems of the Atlantic domain, and are characterized by a peculiar vegetation developing on sandy lithology and poor in nutrients, exposed to high temperatures, low water availability and high salinity (Scarano 2002). Restingas are distributed in Brazil from Amapá to southern Rio Grande do Sul, through an extension of over 9.000 kilometers across 17 states (Cunha 2005). They represent one of the most endangered ecosystems in Brazil because they were historically explored over the centuries, due to the patchy and disordered human occupation from the seashore towards the mainland (Cunha 2005).

Thus, the Grumari restinga, located on the outskirts of a major city (Rio de Janeiro), contributes positively to the conservation of a significant part of the restingas in the state of Rio de Janeiro. The lack of basic information about most floristic groups, including vascular epiphytes, which are a key group for the maintenance of tropical ecosystems
(Benzing 1990), is a relevant problem for the conservation of this remnant. The aim of the present study was to inventory the vascular epiphytes in the Grumari restinga, to categorize species according to the ecological relationship established with their phorophytes and to evaluate the floristic similarity among other restingas in Brazil, where epiphytic flora was studied.

\section{Materials and Methods}

Study site

The Grumari restinga is located in southern Rio de Janeiro state (232'30' $\left.\mathrm{S}, 43^{\circ} 31^{\prime} \mathrm{W}\right)$, in the Grumari Environmental Protection Area (APA Grumari - Fig. 1), between the neighborhoods of Recreio and Barra de Guaratiba. It covers a total area of 951 hectares of restinga vegetation and rocky outcrops (Silva \& Pinheiro 2007).

The climate type is tropical, with hot, rainy summer and dry winter. The annual average temperature and rainfall correspond to $23.6^{\circ} \mathrm{C}$ and $1100 \mathrm{~mm}$, respectively (Moreira et al. 2014). The soil is sandy and saline, and there are swampy areas with organic matter accumulation (Oliveira \& Maia 2005). The Grumari restinga presents six vegetation types: halophilous, psammophilous, post-beach, open shrub, closed shrub and restinga forest (Moreira et al. 2014). We sampled the epiphytic flora in the closed shrub formation dominated by Myrtaceae and Fabaceae, which can reach up to 15 meters high. We also found dense bromeliad clumps, mainly Aechmea sphaerocephala Baker, in the understory.

\section{Floristic inventory}

The floristic inventory of vascular epiphytic species was performed through expeditions undertaken between January and December 2014, using a random walking method (Filgueiras et al. 1994), when fertile plant material samples were collected and processed according to Mori et al. (1989). All samples were deposited in the Federal University of Rio de Janeiro herbarium (RFA). Identifications were made based on taxonomic monographs and floras, through comparison with identified specimens in the R, RB and RFA herbaria, and through consulting with specialists on specific families. The list was supplemented with materials deposited in GUA, RFA, R and RB (see acronyms in Index Herbariorum [Thiers, continuously updated]), and with literature about the studied location (Nogueira et al. 2011; ArboGallas \& Verçoza 2012; Moreira et al. 2014). 
The circumscription of species to family follows APG IV (2016) for angiosperms, Smith et al. (2006) for ferns and Christenhusz et al. (2011) for lycophytes. The taxa names were updated according to supplementary materials in the Brazil Flora Group review (BFG 2015) for angiosperms and Prado et al. (2015) for ferns and lycophytes, and to taxonomic publications, using author abbreviations suggested by Brummitt \& Powell (1992) and IPNI (<http://www.ipni.org $>$ ).

The endangered species were indicated based on the official list available on the Livro Vermelho da Flora do Brasil (Red Book of Brazilian Flora) (Martinelli \& Moraes 2013).

\section{Classification of ecological categories}

Epiphytes were classified in four ecological categories based on the relationship established with the phorophyte, according to Benzing (1990), with modifications by Kersten \& Kuniyoshi (2009): characteristic holoepiphytes (Epi, those that spend the full life cycle on the phorophytes); facultative holoepiphytes (Fac, in the same community, which can grow as epiphytes as well as terrestrial and rupicolous); accidental holoepiphytes (Aci, usually terrestrial/rupicolous, but can casually grow as epiphytes); hemiepiphytes (Hem, only species that spend part of their lives on phorophytes).

Similarity and statistical analysis

A matrix of binary data (presence/absence) compiled from six floristic restinga lists (Tab. 1, Fig. 1), where all the names were updated according to the BFG (2015) was prepared in order to assess the similarity between the epiphytic flora in the Grumari restinga and other Brazilian restingas. To give more strength to the analysis, species not identified to species level and dubious identifications ("similar to" [aff.] or "check" [cf.]) were excluded and different subspecies and varieties were considered as the same species.

Selected sites were compared through cluster analysis, using the Jaccard coefficient as distance measurement (Müeller-Dombois \& Ellenberg

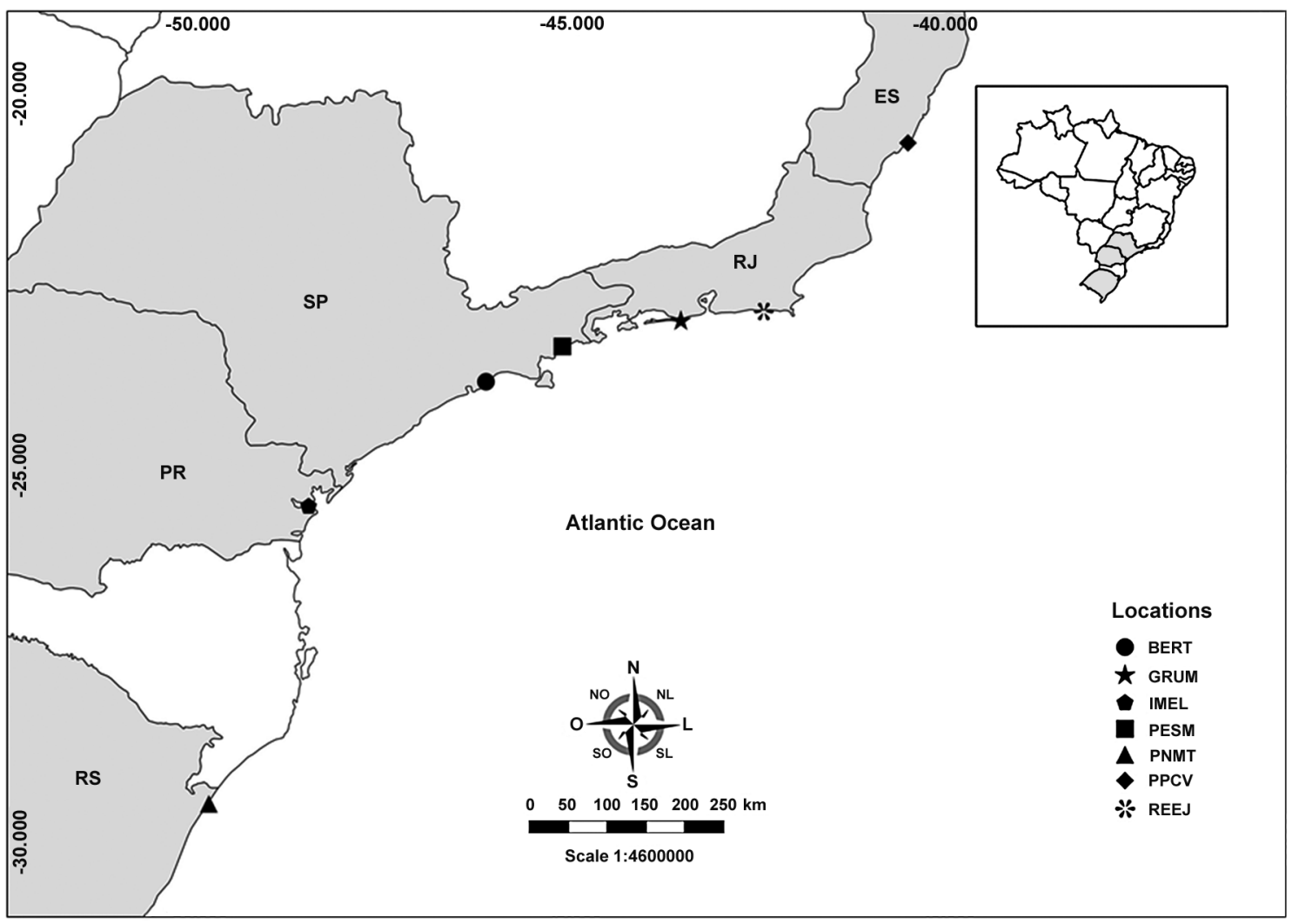

Figure 1 - Map showing the Grumari restinga and location of the areas compared through cluster and ordination analyses (see text for details). 
Table 1 - Restinga data sets evaluated through multivariate analysis and their acronyms (Acr.), sites, state (UF), geographic coordinates and reference sources. (Acronyms: IMEL = Ilha do Mel; PPCV = Parque Estadual Paulo Cesar Vinha; BERT = restingas de Bertioga; REEJ = Reserva Ecológica Estadual de Jacarepiá; PESM = Parque Estadual da Serra do Mar (Núcleo Picinguaba); GRUM = restinga de Grumari).

\begin{tabular}{llllll}
\hline Acr. & Sites & State & Latitude $(\mathbf{S})$ & Longitude $(\mathbf{W})$ & Reference \\
\hline IMEL & Paranaguá & PR & $25^{\circ} 31^{\prime} 67,2^{\prime \prime}$ & $48^{\circ} 18^{\prime} 73,9^{\prime \prime}$ & Kersten \& Silva 2001 \\
PPCV & Setiba & ES & $20^{\circ} 33^{\prime}-20^{\circ} 38^{\prime}$ & $40^{\circ} 23^{\prime}-40^{\circ} 26^{\prime}$ & Assis et al. 2004 \\
BERT & Bertioga & SP & $23^{\circ} 44^{\prime}-23^{\circ} 46^{\prime}$ & $45^{\circ} 55^{\prime}-46^{\circ} 02^{\prime}$ & Martins et al. 2008 \\
REEJ & Saquarema & RJ & $22^{\circ} 47^{\prime}-22^{\circ} 57^{\prime}$ & $42^{\circ} 20^{\prime}-42^{\circ} 43^{\prime}$ & Fontoura et al. 2009 \\
PESM & Ubatuba & SP & $23^{\circ} 21^{\prime}-23^{\circ} 22^{\prime}$ & $44^{\circ} 51^{\prime}-44^{\circ} 52^{\prime}$ & Mania \& Monteiro 2010 \\
PNMT & Arroio do Sal & RS & $29^{\circ} 29^{\prime} 25,13^{\prime}$, & $49^{\circ} 50^{\prime} 36,12^{\prime}$, & Staudt et al. 2012 \\
GRUM & Rio de Janeiro & RJ & $23^{\circ} 02^{\prime}-23^{\circ} 03^{\prime}$ & $43^{\circ} 31^{\prime}-43^{\circ} 32^{\prime}$ & This study \\
\hline
\end{tabular}

1974), and unweighted pair group method with arithmetic mean (UPGMA) as clustering algorithm (Hammer et al. 2001). To evaluate whether the cluster adequately represents the original similarity matrix between areas the cophenetic correlation coefficient (Borcard et al. 2011) was estimated, through a Pearson correlation between the original similarity matrix and cophenetic matrix. A Principal Coordinates Analysis (PCA) was also performed using the same data set to evaluate the existence of groups based on flora similarity. The influence of spatial autocorrelation on the composition of epiphytic species was analyzed using a Mantel test with 10,000 permutations (Legendre \& Legendre 1998) on the similarity and geographical distance between areas matrices. The cluster and PCA analyses were performed using the Paleontological Statistics - PAST v. 1.89 software (Hammer et al. 2001). The cophenetic correlation coefficient analysis and Matel test were performed using $\mathrm{R}$ (R Development Core Team 2015).

\section{Results}

We found 37 vascular epiphyte species in the Grumari restinga, distributed in 21 genera and six families (Tab. 2, Fig. 2). The angiosperm plants represented 32 species, 18 genera and five families, whereas ferns were represented by five species, three genera and one family. Bromeliaceae (13) and Orchidaceae (12) were the most representative epiphyte families; they were followed by the Polypodiaceae, which contributed with five species. These families represent $81 \%$ of the total species sampled. The genera with the largest number of species were Tillandsia (Bromeliaceae), with six species, Microgramma (Polypodiaceae), Billbergia (Bromeliaceae) and Philodendron (Araceae), with three species each. All other genera were represented by fewer species.

Two of the species found in this study are in the flora red list of endangered species, namely: Anthurium luschnathianum, listed as Endangered, and Cattleya guttata, listed as Vulnerable.

The distribution of epiphytic species recorded in the Grumari restinga, according to the ecological relationship categories with phorophytes (Tab. 1, Fig. 2) showed predominance of characteristic holoepiphytes with 23 species $(61 \%)$. Among these species, only one of the Polypodiaceae species (Serpocaulon triseriale) was not included

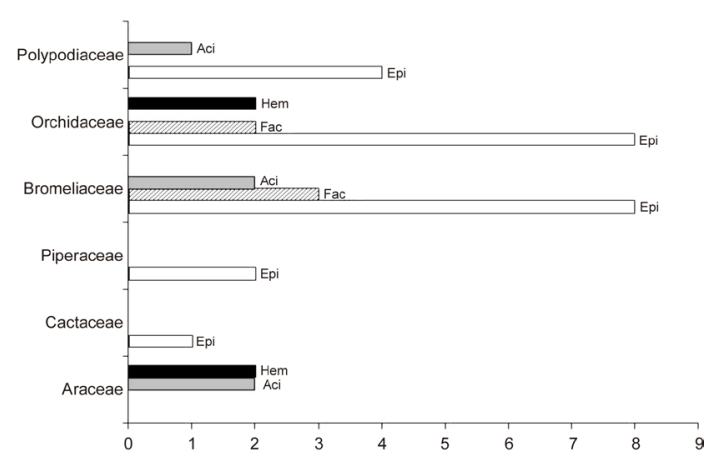

Figure 2 - Participation of vascular epiphyte ecological relationship categories with phorophytes, Grumari restinga, Rio de Janeiro state. Epi = characteristic holoepiphyte; $\mathrm{Fac}=$ facultative holoepiphyte; $\mathrm{Aci}=$ accidental holoepiphyte; Hem $=$ hemiepiphyte. 
Table 2 - List of vascular epiphytes sampled at the Grumari restinga, Rio de Janeiro state, Brazil. Cat = ecological relationship category; Epi = characteristic holoepiphyte; $\mathrm{Fac}=$ facultative holoepiphyte; Aci = accidental holoepiphyte; Hem $=$ hemiepiphyte; ${ }^{*}=$ Endemic to Rio de Janeiro.

\begin{tabular}{|c|c|c|}
\hline Family/ species & Cat. & Voucher \\
\hline \multicolumn{3}{|l|}{ Araceae (4) } \\
\hline *Anthurium luschnathianum Kunth. & Aci & D.R.Couto 2597 (RFA) \\
\hline Philodendron corcovadense Kunth. & Hem & not collected \\
\hline Philodendron cf. cordatum Kunth. & Hem & not collected \\
\hline Philodendron crassinervium Lindl. & Aci & D.R.Couto 2590 (RFA) \\
\hline \multicolumn{3}{|l|}{ Bromeliaceae (12) } \\
\hline Aechmea nudicaulis (L.) Griseb. & Epi & D.R.Couto 3053 (RFA) \\
\hline Aechmea sphaerocephala Baker & Aci & B.R.Silva 1471 (RB) \\
\hline Billbergia pyramidalis (Sims) Lindl. & $\mathrm{Fac}$ & D.Sucre 3379 (RB) \\
\hline Billbergia zebrina (Herb.) Lindl. & Epi & D.Sucre 3528 (RB) \\
\hline Billbergia amoena (Lodd.) Lindl. & Aci & D.R.Couto 3048 (RFA) \\
\hline Neoregelia sarmentosa (Regel) L.B.Sm. & $\mathrm{Fac}$ & N.Vasconcellos 28 (RB) \\
\hline Tillandsia geminiflora Brongn. & Epi & D.Sucre $3514(\mathrm{RB})$ \\
\hline Tillandsia mallemontii Glaz. ex Mez & Epi & D.R.Couto 2575 (RFA) \\
\hline Tillandsia recurvata $(\mathrm{L}.) \mathrm{L}$. & Epi & not collected \\
\hline Tillandsia stricta Sol. & Epi & D.R.Couto 2576 (RFA) \\
\hline Tillandsia tricholepsis Baker & Epi & D.R.Couto 2581 (RFA) \\
\hline Tillandsia usneoides L. & Epi & D.R.Couto 2584 (RFA) \\
\hline Vriesea procera (Mart. ex Schult. \& Schult.f.) Wittm. & Fac & A.Oliveira 107 (RB) \\
\hline \multicolumn{3}{|l|}{ Cactaceae (1) } \\
\hline Hylocereus setaceus (Salm-Dyck) R.Bauer & Epi & L.Scheinvar 1306 (RB) \\
\hline \multicolumn{3}{|l|}{ Orchidaceae (12) } \\
\hline Alatiglossum ciliatum (Lindl.) Baptista & Epi & M.M.Moreira 28 (RFA) \\
\hline Brassavola tuberculata Hook. & $\mathrm{Fac}$ & D.Sucre $3384(\mathrm{RB})$ \\
\hline Campylocentrum micranthum (Lindl.) Maury & Epi & M.M.Moreira 155 (RFA) \\
\hline Campylocentrum sp. & Epi & not collected \\
\hline Catasetum luridum Lindl. & Epi & M.M.Moreira 102 (RFA) \\
\hline Cattleya forbesii Lindl. & Epi & F.P.Uribbe s.n. (RFA) \\
\hline Cattleya guttata Lindl. & Fac & D.S.D.Araujo 5468 (GUA) \\
\hline Epidendrum pseudodifforme Hoehne \& Schltr. & Epi & D.S.D.Araujo 5085 (GUA) \\
\hline Polystachya concreta (Jacq.) Garay \& Sweet & Epi & not collected \\
\hline Sophronitis cernua Lindl. & Epi & M.Nadruz 385 (RB) \\
\hline Vanilla chamissonis Klotzsch & Hem & M.M.Moreira 93 (RFA) \\
\hline Vanilla bahiana Hoehne & Hem & M.M.Moreira 101 (RFA) \\
\hline \multicolumn{3}{|l|}{ Piperaceae (2) } \\
\hline Peperomia arifolia Miq. & Epi & D.Sucre 3347 (RB) \\
\hline Peperomia tetraphylla (G.Forst.) Hook. \& Arn. & Epi & D.Sucre $3532(\mathrm{RB})$ \\
\hline \multicolumn{3}{|l|}{ Polypodiaceae (5) } \\
\hline Microgramma aff. persicariifolia (Schrad.) C.Presl & Epi & not collected \\
\hline Microgramma lindbergii (Mett.) de la Sota & Epi & N.F.S.Marquete 51 (RB) \\
\hline Microgramma vacciniifolia (Langsd. \& Fisch.) Copel. & Epi & D.R.Couto 2574 (RFA) \\
\hline Pleopeltis pleopeltifolia (Raddi) Alston & Epi & D.R.Couto 2573 (RFA) \\
\hline Serpocaulon triseriale (Sw.) A.R.Sm. & Aci & D.R.Couto 2588 (RFA) \\
\hline
\end{tabular}


in this category. Facultative holoepiphytes were represented by five species $(13.5 \%)$, three Bromeliaceae and two Orchidaceae species. Five species $(13.5 \%)$ were recorded as accidental epiphytes. The group was formed by species that were described as terrestrial in the literature, but were found vegetating on phorophyte structures. Hemiepiphytes totaled four species (10.8\%) distributed in Araceae and Orchidaceae.

The cluster analysis indicated three groups presenting low similarity values in Rio de Janeiro and Espírito Santo (group A), in disjunct areas in São Paulo [group B (group B corresponds to Paraná and Rio Grande do Sul, would be good to standardize] and in southern Brazil [Paraná and Rio Grande do Sul states, group C (cluster $\mathrm{C}$ in the PCA figure corresponds to São Paulo localities, would be good to standardize)] (Fig. 3). This cluster represents clearly the similarity between the areas (cophenetic correlation coefficient $r=$ $0.9)$. The PCA showed the following values and variance percentages for the first three ordination axes: $0.587(24.47 \%), 0.45(18.69 \%)$ and 0.38 (15.97\%), respectively. This ordering showed the three groups (A, B and C) found through cluster analysis, as shown in Fig. 4. A significant correlation between the geographical distance and the species composition was observed in the areas (Mantel $r=0.33 ; p=0.04$ ) (Figs. 3; 4).

Group A (Grumari, Saquarema and Setiba), located in Rio de Janeiro and Espírito Santo states, shared five species (Aechmea nudicaulis Alatiglossum ciliatum, Tillandsia stricta, T. usneoides and Vriesea procera), which causes the
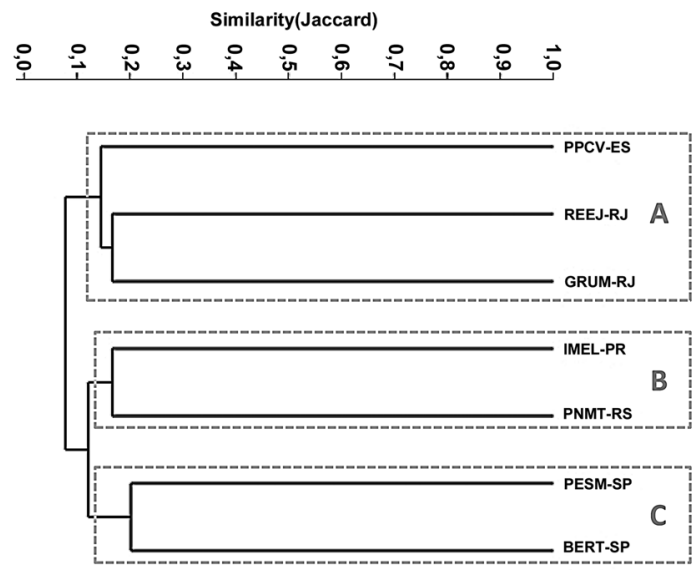

Figure 3 - Cluster analysis of results from eastern Brazil restinga areas based on the Jaccard similarity index, showing formation of three groups.

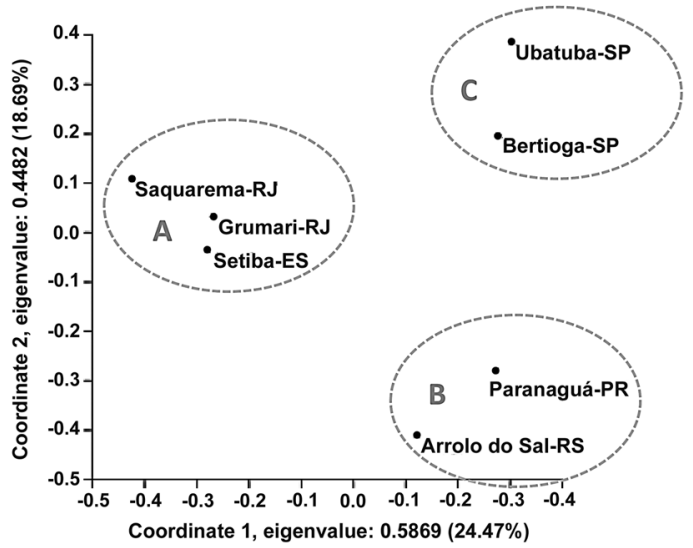

Figure 4 - Principal Coordinates Analysis ( $\mathrm{PCoA}$ ) comparing species composition from restingas at the seven studied sites (see text for details), highlighting the three groups (A, B and C) in the first two axes $(43.16 \%$ of the total variance).

similarity between them to be greater (Fig. 3). Of the species total, $40.5 \%$ ( 15 species) were exclusive to restinga Grumari: Aechmea sphaerocephala, Anthurium luschnathianum, Billbergia zebrina, Catasetum luridum, Epidendrum pseudodifforme, Microgramma lindbergii, Neoregelia sarmentosa, Peperomia arifolia, Peperomia tetraphylla, Philodendrum cordatum, Sophronitis cernua, Tillandsia mallemontii, T. recurvata, T. tricholepis and Vanilla bahiana. Only Aechmea nudicaulis was found in all seven areas, and Tillandsia usneoides in six.

\section{Discussion}

The distribution of species and families follows a trend observed in the research on epiphytic flora conducted in the Brazilian Atlantic Forest, where a large number of species were found in few families (Mania \& Monteiro 2010; Staudt et al. 2012; Blum et al. 2012; Leitman et al. 2014; Alves \& Menini Neto 2014; Barbosa et al. 2015; Couto et al. 2016a; Freitas et al. 2016). This pattern can be explained by the low level of specialization to epiphytism by families in general, causing few families (mainly Orchidaceae, Bromeliaceae, Polypodiaceae and Araceae) to represent a significant part of species richness, such as Orchidaceae, which includes approximately 68\% of the world epiphytic flora (ca. 19,000 species) (sensu Zotz 2013).

Bromeliaceae and Orchidaceae $(67.6 \%$ of the total total recorded species) are the richest families 
and also the richest groups in Brazilian restingas (Kersten \& Silva 2001; Assis et al. 2004; Martins et al. 2008; Mania \& Monteiro 2010; Staudt et al. 2012), as well as in other ecosystems of the Atlantic domain (Rogalski \& Zanin 2003; Dettke et al. 2008; Kersten \& Kuniyoshi 2009; Blum et al. 2012; Freitas \& Assis 2013; Leitman et al. 2014; Barbosa et al. 2015; Couto et al. 2016a; Couto et al. 2016b). They also appear as the richest families in summaries of taxonomic composition of vascular epiphytes worldwide (Gentry \& Dodson 1987; Benzing 1990; Zotz 2013) and in the Atlantic Forest (Freitas et al. 2016).

The epiphyte richness in Grumari restinga can be considered to be average, but it is greater than the epiphytic richness of other inventories carried out in the coastal plains of the southeastern and southern regions of Brazil, as recorded by Fontoura et al. (2009) in Rio de Janeiro (Saquarema), and by Assis et al. (2004) for Setiba restingas in Espírito Santo state (24 spp.). However, the richness was lower than that of restingas of São Paulo (Mania \& Monteiro 2010 - 64 spp.; Martins et al. 2008 90 spp.) and Paraná states (Kersten \& Silva 2001 - 77 spp.) and of the coastal plains of Rio Grande do Sul state (Staudt et al. 2012 - 40 spp.). The low similarity values between areas are possibly related to the different phytophysiognomic features found in the studies considered (which include different ecosystems and geographical regions), and in the level of floristic inclusion (Assis et al. 2004; Fontoura et al. 2009; Martins et al. 2008). In vascular epiphyte studies, the effort to register ferns and lycophytes is essential, since this group significantly supports the richness and diversity of the epiphytic flora worldwide (Zotz 2013) and in the Atlantic domain (Freitas et al. 2016).

Dominant physiognomy of the restinga in the current study is of closed shrub and dense vegetation dominated by Myrtaceae species, thus corroborating what was recorded by Araújo \& Henriques (1984) when they mentioned a Myrtaceae thicket. This shrubby vegetation presents shorter individuals and lacks large phorophytes. The greatest richness observed in many studies is probably related to studied restinga vegetation forest types. These areas present greater availability of niches provided by forest stratification (from shrubs, treelets and trees in the understory to large trees in the upper canopy), thus offering greater heterogeneity of micro-habitats used for epiphyte colonization. The occurrence of large trees and favorable climatic factors (high humidity and mild temperatures) have been reported as the main factors related to the high diversity of epiphytes in the tropical region (Woods et al. 2015; Zhao et al. 2015; Ding et al. 2016).

The predominance of species in the characteristic holoepiphytes ecological category $(61 \%)$ is a common pattern, and it is corroborated by several studies of the Brazilian epiphytic flora (Kersten \& Silva 2001; Kersten \& Kuniyoshi 2009; Mania \& Monteiro 2010; Geraldino et al. 2010; Blum et al. 2011; Barbosa et al. 2015; Couto et al. 2016a; Couto et al. 2016b). Three out of the five species classified as facultative holoepiphytes belong to family Bromeliaceae (Billbergia pyramidalis, Neoregelia sarmentosa and Vriesea procera), and two to Orchidaceae, namely: Cattleya guttata and Brassovala tuberculata, which are common in the study area. Fraga \& Peixoto (2004) observed C. guttata and B. tuberculata as optional holoepiphytes for shrub formations in restinga areas in Espírito Santo state, whereas in forest formations (hillside forest and forest on tertiary "trays") they tend to occur as characteristic holoepiphytes.

Accidental holoepiphytes were represented by five terrestrial species which are abundant in the study area, but eventually occur as epiphytes on shrubs. Aechmea sphaerocephala forms large thickets on the restinga soil. Philodendron crassinervium and Serpocaulon triseriale are also widely distributed throughout the studied area. A similar share of facultative and accidental holoepiphytes, which together account for $27 \%$ of all the analyzed species, would possibly be due to the physical characteristics of the restinga soil, whose surface horizon is mainly formed by nondecomposed organic matter and mycelium fungi. This forms a substrate very similar to that found in the canopy (Kersten \& Silva 2001). According to Araújo \& Henriques (1984) the study area has a dense shrubby vegetation physiognomy, which presents short trees and lack a defined intermediate stratum. These features facilitate the penetration of solar radiation in the "forest", and work as an important factor for establishment of epiphytes directly on soil, along with the faster drainage system observed in restingas areas. Other researchers (Kersten \& Silva 2001; Fraga \& Peixoto 2004) also highlighted the occurrence of facultative and accidental epiphyte restingas in southern and southeastern Brazil, which suggests that the same vegetation and substrate structural characteristics are the constraint of these occurrences. 
We observed that the low similarity values influenced by the small number of species shared between areas (even between areas that are close to each other) reflects the intrinsic floristic particularities of each area. These values result from the great diversity in Brazilian restinga physiognomies, which are influenced by the biotic and abiotic heterogeneity (Araújo \& Henriques 1984; Araújo et al. 2004).

The results presented by the cluster and PCA analyses and Mantel test indicated the influence of geographical distance on the similarities between the areas, thus demonstrating that geographically closer areas tend to be more similar to each other, even if they do not share similar ecological conditions. The areas forming group $\mathrm{A}$, which are represented by restingas in Rio de Janeiro and Espírito Santo states, reinforce previous hypotheses that the restinga in Rio de Janeiro is more similar to that in Espírito Santo state (Araújo 2000). According to Thomas (1991) and Assis et al. (2004), the great similarity between the restingas in Rio de Janeiro and Espírito Santo is due to the phytophysionomic similarities between these states.

Our study provides the first contribution to the knowledge about the epiphytic flora in the Grumari restinga and shows a singular flora with $40 \%$ of unique species occurring in this location, a fact that highlights its importance as conservation area. We also show the importance of preserving the Grumari restinga as a way to preserve the regional flora, because it houses endangered species and indicates the need for more detailed studies on vascular epiphytic plants, including the structure of this community and the influence of different restinga types on the vascular epiphytic flora diversity.

\section{Acknowledgments}

The authors would like to thank the Pos-graduate program in Botany, Museu Nacional/Universidade Federal do Rio de Janeiro for the logistical support and Coordenação de Aperfeiçoamento de Pessoal de Nível Superior (CAPES) and Conselho Nacional de Desenvolvimento Científico e Tecnológico (CNPq) for the financial support. Thanks also to Good Deal Consultoria for the English revision.

\section{References}

Alves, F.E. \& Menini Neto, L. 2014. Vascular epiphytes in a forest fragment of Serra da Mantiqueira and floristic relationships with Atlantic high altitude áreas in Minas Gerais. Brazilian Journal of Botany 37:187-196.
Araújo, D.S.D. 2000. Análise florística e fitogeográfica das restingas do estado do Rio de Janeiro. Tese de Doutorado. Instituto de Biologia. Universidade Federal do Rio de Janeiro, Rio de Janeiro. 176p.

Araújo, D.S.D. \& Henriques, R.P.B. 1984. Análise florística das restingas do estado do Rio de Janeiro. In: Lacerda, L.D. de et al. (eds.). Restingas: origem, estrutura e processos. CEUFF, Niterói. Pp. 159-194.

Araújo, D.S.D.; Pereira, M.C.A. \& Pimentel, M.C.P. 2004. Flora e estrutura de comunidades na Restinga de Jurabatiba - síntese dos conhecimentos com enfoque especial para a formação aberta de Clusia. In: Rocha, C.F.D.; Esteves, F.A. \& Scarano, F.R. (eds.). Pesquisas de longa duração na Restinga de Jurabatiba: ecologia, história natural e conservação. RIMa, São Carlos. Pp. 59-76.

Arbo-Gallas, D. \& Verçoza, F.C. 2012. A família Cactaceae na Restinga de Grumari, Rio de Janeiro, RJ, Brasil. Revista Eletrônica de Biologia 5: 129-143.

Assis, A.M.; Thomaz, L.D. \& Pereira, O.J. 2004. Florística de um trecho de floresta de restinga no município de Guarapari, Espírito Santo, Brasil. Acta Botanica Brasilica 18: 191-201.

Barbosa, D.E.F.; Basílio, G.A.; Silva, F.R. \& Menini Neto, L. 2015. Vascular epiphytes in a remnant of seasonal semideciduous forest in the zona da mata, state of Minas Gerais, Brazil. Bioscience Journal 31: 623-633.

Barbosa, M.D.; Becker, D.F.P.; Cunha, S.; Droste, A. \& Schmitt, J.L. 2015. Vascular epiphytes of the Atlantic Forest in the Sinos River basin, state of Rio Grande do Sul, Brazil: richness, floristic composition and community structure. Brazilian Journal of Botany 75: 25-35.

Basílio, G.A.; Barbosa, D.E.F.; Furtado, S.G.; Silva, F.R. \& Menini Neto, L. 2015. Community ecology of epiphytic Bromeliaceae in a remnant of Atlantic Forest in Zona da Mata, Minas Gerais State, Brazil. Hoehnea 42: 21-31.

Benzing, D.H. 1990. Vascular epiphytes. Cambridge University Press, New York. 354p.

BFG. 2015. Growing knowledge: an overview of seed plant diversity in Brazil. Rodriguésia 66: 1085-1113.

Blum, C.T.; Roderjan, C.V. \& Galvão, F. 2011. Floristic composition and altitudinal distribution of vascular epiphytes in the Ombrophilous Dense Forest of the Prata Mountain Range, Morretes, Paraná state, Brazil. Biota Neotropica 11: 141-159.

Borcard, D.; Gillet, F. \& Legendre, P. 2011. Numerical Ecology with R. Springer, New York. 306p.

Brummitt, R.K. \& Powell, C.E. 1992. Authors of plant names. Royal Botanic Gardens, Kew. 732p.

Christenhusz, M.J.M.; Zhang, X.C. \& Schneider, H. 2011. A linear sequence of extant families and genera of lycophytes and ferns. Phytotaxa 19: 7-54.

Couto, D.R.; Dias, H.M.; Pereira, M.C.A.; Fraga, C.N. \& Pezzopane, J.E.M. 2016a. Vascular epiphytes 
on Pseudobombax (Malvaceae) in rocky outcrops (inselbergs) in Brazilian Atlantic Rainforest: basis for conservation of a threatened ecosystem. Rodriguésia 67: 583-601.

Couto, D.R.; Fontana, A.P.; Kollmann, L.J.C.; Manhães, V.C.; Francisco, T.M. \& Cunha, G.M. 2016 b. Vascular epiphytes in seasonal semideciduous forest in the state of Espírito Santo and the similarity with other seasonal forests in Eastern Brazil. Acta Scientiarum (Biological Sciences) 38: 169-177.

Cunha, I. 2005. Desenvolvimento sustentável na costa brasileira. Revista Galega de Economia 14: 1-14.

Dettke, G.A.; Orfrini, A.C. \& Milaneze-Gutierre, M.A. 2008. Composição florística e distribuição de epífitos vasculares em um remanescente alterado de Floresta Estacional Semidecidual no Paraná, Brasil. Rodriguésia 59: 859-872.

Dislich, R. \& Mantovani, W. 2016. Vascular epiphyte assemblages in a Brazilian Atlantic Forest fragment: investigating the effect of host tree features. Plant Ecology 217: 1-12.

Filgueiras, T.S.; Nogueira, P.E.; Brochado, A.L. \& Guala, G.F. 1994. Caminhamento: um método expedito para levantamentos florísticos qualitativos. Cadernos de Geociências 12: 39-43.

Fontoura, T.; Rocca, M.A.; Schilling, A.C. \& Reinert, F. 2009. Epífitas da floresta seca da reserva ecológica estadual de Jacarepiá: Relações com a comunidade arbórea. Rodriguésia 60: 171-185.

Freitas, J. \& Assis, A.M. 2013. Estrutura do componente epífito vascular em trecho de floresta atlântica na região serrana do Espírito Santo. Árvore 37: 815-823.

Freitas, L.; Salino, A.; Menini Neto, L.; Almeida, T.E.; Mortara, S.R.; Stehmann, J.R.; Amorim, A.M.; Guimarães, E.F.; Coelho, M.N.; Zanin, A. \& Forzza, R.C. 2016. A comprehensive checklist of vascular epiphytes of the Atlantic Forest reveals outstanding endemic rates. PhytoKeys 58: 65-79.

Furtado, S.G. \& Menini Neto, L. 2015. Diversity of vascular epiphytes in two high altitude biotopes of the Brazilian Atlantic Forest. Brazilian Journal of Botany 38: 295-310.

Gentry, A. \& Dodson, C.H. 1987. Diversity and biogeography of neotropical vascular epiphytes. Annals of the Missouri Botanical Garden 74: 205233.

Hammer, Ö.; Harper, D.A.T. \& Ryan, P.D. 2001. PAST: Paleontological statistics software package for education and data analysis. Paleontologia Electronica 4: 9.

Hoeltgebaum, M.P.; Queiroz, M.H. \& Reis, M.S. 2013. Relação entre bromélias epifíticas e forófitos em diferentes estádios sucessionais. Rodriguésia 64: 337-347.

Kersten, R.A. \& Silva, S.M. 2001. Composição florística e estrutura do componente epifítico vascular em floresta da planície litorânea na Ilha do Mel, Paraná, Brasil. Revista Brasileira de Botânica 24: 213-226.
Kersten, R.A. \& Kuniyoshi, Y.S. 2009. Conservação das florestas na Bacia do Alto Iguaçu, Paraná - Avaliação da comunidade de epífitos vasculares em diferentes estágios serais. Floresta 39: 51-66.

Krömer, T.; Kessler, M. \& Gradstein, S.R. 2007. Vertical stratification of vascular epiphytes in submontane and montane forest of the Bolivian Andes: the importance of the understory. Plant Ecology 189: 261-278.

Leitman, P.; Amorim, A.; Menini Neto, L. \& Forzza, R.C. 2014. Epiphytic angiosperms in a mountain forest in southern Bahia, Brazil. Biota Neotropica. 14: 1-12.

Legendre, P. \& Legendre, L. 1998. Numerical Ecology. Developments in environmental modelling, 20. Elsevier, New York. 853p.

Ding, L.; Liu, G.; Zang, R.; Zhang, J.; Lu, X. \& Huang, J. 2016. Distribution of vascular epiphytes along a tropical elevational gradient: disentangling abiotic and biotic determinants. Scientific Reports 6: 19706. DOI: $10.1038 /$ srep 19706

Mania, L.F. \& Monteiro, R. 2010. Florística e ecologia de epífitos vasculares em um fragmento de floresta de restinga, Ubatuba, SP, Brasil. Rodriguésia 61: 705-713.

Martinelli, G. \& Moraes, M.A. 2013. Livro vermelho da flora do Brasil. Instituto de Pesquisas Jardim Botânico do Rio de Janeiro, Rio de Janeiro. 1100p.

Martins, S.E.; Rossi, L.; Sampaio, P.S.P. \& Magenta, M.A.G. 2008. Caracterização florística de comunidades vegetais de restinga em Bertioga, SP, Brasil. Acta Botanica Brasilica 22: 249-274.

Menini Neto, L.; Furtado, D.G.; Zappi, D.C.; Oliveira Filho, A.T. \& Forzza, R.C. 2015. Biogeography of epiphytic Angiosperms in the Brazilian Atlantic forest, a world biodiversity hotspot. Revista Brasileira de Botânica 39: 261-273.

Moreira, M.M.; Barberena, F.F.V.A. \& Lopes, R.C. 2014. Orchidaceae of the Grumari restinga: floristic and similarity among restingas in Rio de Janeiro state, Brazil. Acta Botanica Brasilica 28: 321-326.

Mori, A.S.; Silva, L.A.M.; Lisboa, G. \& Coradini. L. 1989. Manual de Manejo do Herbário Fanerogâmico. Centro de Pesquisa do Cacau, Ilhéus. 104p.

Müeller-Dombois, D. \& Ellenberg, H. 1974. Aims and methods of vegetation ecology. John Wiley, New York. 547p.

Myers, N.; Mittermeier, R.A.; Mittermeier, C.G.; Fonseca, G.A. \& Kent, J. 2000. Biodiversity hotspots for conservation priorities. Nature 403: 853-858.

Nogueira, A.C.; Côrtes, I.M.R. \& Verçoza, F.C. 2011. A família Bromeliaceae na Área de Proteção Ambiental de Grumari, Rio de Janeiro, RJ, Brasil. Natureza on line 9: 91-95.

Oliveira, J.C. \& Maia, V.C. 2005. Ocorrência e caracterização de galhas de insetos na restinga de Grumari, RJ. Arquivos do Museu Nacional/UFRJ. 63: 669-675. 
Prado, J.; Sylvestre, L.S.; Labiak, P.H.; Windisch, P.G.; Salino, A.; Barros, I.C.L.; Hirai, R.Y.; Almeida, T.E.; Santiago, A.C.P.; Kieling-Rubio, M.A.; Pereira, A.F.N.; Øllgaard, B.; Ramos, C.G.V.; Mickel, J.T.; Dittrich, V.A.O.; Mynssen, C.M.; Schwartsburd, P.B.; Condack, J.P.S.; Pereira, J.B.S. \& Matos, F.B. 2015. Diversity of ferns and lycophytes in Brazil. Rodriguésia 66. DOI: 10.1590/2175-7860201566410

R Core Team. 2015. R: a language and environment for statistical computing. R Foundation for Statistical Computing. Vienna, Austria. Avaliable at $<$ http:// www.R-project.org/>. Access on 5 August 2015.

Rogalski, J.M. \& Zanin, E.M. 2003. Composição florística de epífitos vasculares no estreito de Augusto César, Floresta Estacional Decidual do Rio Uruguai, RS. Revista Brasileira Botânica 26: 551-556.

Scarano, F.R. 2002. Structure, function and floristic relantioships of plants communities in stressful habitats marginal to Brazilian Atlantic Rainforest. Annals of Botany 90: 517-524.

Silva, A.L.G. \& Pinheiro, M.C.B. 2007. Biologia floral e polinização de quatro espécies de Eugenia L. (Myrtaceae). Acta Botanica Brasilica 21: 235-247.

Smith, A.R.; Pryer, K.M.; Schuettpelz, E.; Korall, P.; Schneider, H. \& Wolf, P.G. 2006. A classification for extant ferns. Taxon 55: 705-731.

Staudt, M.G.; Lippert, A.P.U.; Cunha, S.; Becker, D.F.P.; Marchioretto, M.S. \& Schmitt, J.L. 2012. Composição florística de epífitos vasculares do Parque Natural Municipal Tupancy, Arroio do Sal, RS - Brasil. Pesquisas Botânica 63: 177-188.
The Angiosperm Phylogeny Group - APG IV. 2016. An update of the Angiosperm Phylogeny Group classification for the orders and families of flowering plants: APG IV. Botanical Journal of the Linnean Society 181: 1-20.

Thiers, B. [continuously updated]. Index Herbariorum: A global directory of public herbaria and associated staff. New York Botanical Garden's Virtual Herbarium. Available at $<$ http://sweetgum. nybg.org/ih/>. Access on June 2015.

Thomaz, L.D. 1991. Distribuição e diversidade de espécies na vegetação halófila-psamófila no Litoral do Espírito Santo. Dissertação de Mestrado em Ciências Biológicas - Biologia Vegetal. Universidade Estadual Paulista, São Paulo. 143p.

Wängler, M.S.; Barberena, F.F.V.A. \& Lopes, R.C. 2015. Orchidaceae in an Atlantic Forest area: floristics and similarity to other Dense Ombrophilous Forest fragments. Acta Botanica Brasilica 29: 82-93.

Woods, C.L.; Cardelús, C.L. \& Dewalt, S.J. 2015. Microhabitat associations of vascular epiphytes in a wet tropical forest canopy. Journal of Ecology 103: 421-430.

Zhao, M.; Geekiyanage, N.; Xu, J.; Khin, M.M.; Nurdiana, D.R.; Paudel, E. \& Harrison, R.D. 2015. Structure of the epiphyte community in a tropical montane forest in SW China. Plos One 10: e0122210. DOI:10.1371/ journal.pone.0122210

Zotz, G. 2013 The systematic distribution of vascular epiphytes - a critical update. Botanical Journal of the Linnean Society 171: 453-481. 